\title{
REGIONAL MODEL OF DISPERSED ENERGY OF THE WEST POMERANIAN REGION
}

\author{
MARCIN RABE \\ University of Szczecin, Faculty of Management and Economics of Services, POLAND \\ e-mail: marcin.rabe@wzieu.pl
}

\begin{abstract}
\begin{tabular}{l|l} 
RECEIVED & 10 December 2018
\end{tabular}
ACCEPTED 28 December 2018

JEL

CLASSIFICATION

Q42, Q56

KEYWORDS renewable energy sources, lexographic method, distributed generation

ABSTRACT The presented article attempts to identify and analyze the conditions for running a regional energy policy, with particular emphasis on renewable energy sources in a given area. The aim of the article is to build a mathematical model of dispersed energy, related to the regional development strategy, and to generate a development scenario taking into account the criteria of sustainable development, i.e. economic, ecological and social. A lexicographic method was used to obtain a compromise solution in the distributed energy model of multi-criteria methods. The research material in the article comes from many sources, both domestic and foreign, including empirical data from the Central Statistical Office, energy and fuel institutes, regional energy institutions.
\end{abstract}

\section{Introduction}

World energy policy has been changing dynamically for many years, and these changes can be seen both at the local and global level. The direction of change is most visible in the increased interest in renewable energy sources. Most consumers are unaware of the high environmental costs involved in generating energy. The solution to the problem may be the generation of energy from dispersed energy sources. Dependence on the distance and 
collection of raw materials as well as the production of energy from local energy sources causes a significant, even by $50 \%$, reduction of costs, while activating the population in the area of development of renewable raw materials. Distributed energy systems allow effective use of market mechanisms in power engineering (Strzelecki, Benysek, Dębicki, 2004).

This article is devoted to the construction of a regional model of distributed energy in the West Pomeranian Region.

\section{Litepature review}

Technological progress, which occurred in recent years, caused the emergence of a new range of medium and low power generation units on the market, most often available in modular designs. These sources are easy to assemble and are characterized by short investment cycles, in addition, they work in a maintenance-free manner. These advantages make these devices in many countries perceived as an attractive alternative to large sources of electricity and heat. For energy sources with the ability to cooperate with existing power systems, the term "distributed generation" is used, while for autonomous sources working outside the system, sometimes the term "dispersed generation" is used (Mokrzycki, 2003).

In Poland, the generation of distributed energy is called "small (with rated power up to 50-150 MW) units or generation facilities, connected directly to distribution networks or located in the electricity grid of the recipient, not subject to central development planning and power management, often producing electricity from energy renewable or unconventional.

The reason for the development of dispersed sources is the liberalization of the energy market, which leads to increased competition. The reduction of conventional raw materials has forced energy companies to look for new sources of income.

In recent years, the importance of security of supply and related efforts to diversify energy sources have increased. The market for renewable energy technologies has made enormous progress, contributing to the development of dispersed sources. The increasing environmental protection requirements as well as the rising costs of production and transmission of energy from centralized sources contribute to the development of dispersed sources. Lack of interregional connections, preventing free flow of electricity between areas and difficulties in the construction of new transmission networks, also contribute to the development of OZE (Skoczkowski, Baran, 2014).

\section{Methods}

In the construction of a regional model of distributed energy in the of the West Pomeranian Region, attention should be paid to the problem of choosing a decision and planning energy production. Each decision sometimes has very far-reaching consequences, and its consequences are often very complex. In the case of choosing the optimal variant in the energy production planning in the region, the choice must be multi-faceted, taking into account various problems. When assessing energy production options, one can not rely only on the financial analysis of an investment, and one should also take into account very important issues such as: environmental aspects (ecological costs, loss of soil fertility), agroenergetic aspects, technological aspects, organizational aspects or social aspects.

The decision about choosing the variant of the project implementation in energy production planning in the West Pomeranian Region also requires examining the options in terms of their positive and negative impact. Positive aspects include benefits and opportunities, while the negative elements include costs and risks. The problem with 
the assessment of these aspects is often the difficulty of expressing them in numerical terms. For example, some of the benefits are qualitative, at least environmental or risk elements (Sobczyk, Wota, Krężołek, 2011).

The research material is taken from many sources, both domestic and foreign, among others empirical data from the Central Statistical Office, scientific institutes of energy and fuels, regional energy institutions.

The following research methods were used in the article:

1. Analysis of the literature on the subject, allowing to achieve cognitive and research goals.

2. Multicriteria methods of the region's energy efficiency optimization model with the use of several objective functions:

- minimization of energy production costs,

- maximizing the level of production of alternative energy sources,

- minimizing the adverse impact of primary energy production on the natural environment (soil fertility),

- minimization of greenhouse gas emissions in the region.

A lexicographic method was used to obtain a compromise solution from the group of multi-criteria methods.

The lexicographic method requires establishing the hierarchy of criteria validity, and then the variants are set in order to maximize the values of these criteria in sequence. This method allows obtaining a ranking in a short time, even without the help of a computer, but requires the assumption of criteria priority (Kasprzak, 1992, p. 143).

The dispersed energy market in the West Pomeranian Region shapes the new model of the competitive market, opens the possibility of access to the energy market, especially new entities, forcing the operation of electricity prices at market conditions.

The fundamental technical requirement of renewable and unconventional energy sources connected to the power system in the West Pomeranian Region is to provide the appropriate energy quality, power reliability, the possibility of forecasting production and load, and cooperation with security automation (Strzelecki, Kukluk, 2000, pp. 379-384). Table 1 presents the advantages and disadvantages of using dispersed electricity in the West Pomeranian Region.

Tahle 1. Advantages and disadvantages of using dispersed electricity in the West Pomeranian Region

\begin{tabular}{|c|c|c|}
\hline Criterion & Benefits & Disadvantages \\
\hline 1 & 2 & 3 \\
\hline $\begin{array}{l}\text { Decentralization } \\
\text { of production }\end{array}$ & $\begin{array}{l}\text { - locating sources near recipients can increase their } \\
\text { awareness of energy use, environmental impact, } \\
\text { - limiting possible consequences for the large unit failure } \\
\text { system, } \\
\text { - creation of many autonomous entities }\end{array}$ & $\begin{array}{l}\text { - the unit operating costs of generation can be higher than } \\
\text { for large power plants, } \\
\text { - short-circuit power levels may increase near small } \\
\text { sources }\end{array}$ \\
\hline Energy losses & $\begin{array}{l}\text { - minimization of transmission and distribution losses } \\
\text { when the sources are located close enough to the } \\
\text { recipients }\end{array}$ & $\begin{array}{l}\text { - in the case of large dispersed generation units deprived } \\
\text { of nearby customers, the losses may be higher than for } \\
\text { centralized generation }\end{array}$ \\
\hline $\begin{array}{l}\text { Transmission and } \\
\text { distribution costs }\end{array}$ & $\begin{array}{l}\text { - lowering the costs of network progress, } \\
\text { - minimization of actual network restrictions }\end{array}$ & $\begin{array}{l}\text { - scattered sources can create a demand for reactive } \\
\text { power, negatively affecting the voltage levels in the } \\
\text { network, } \\
\text { - the exodus of sources in the network may hinder its } \\
\text { control and increase the costs of automation }\end{array}$ \\
\hline $\begin{array}{l}\text { Impact on the } \\
\text { environment }\end{array}$ & $\begin{array}{l}\text { - benefits resulting from the use of renewable sources, } \\
\text { combined generation of electricity and heat, low- } \\
\text { emission fuels (natural gas) }\end{array}$ & $\begin{array}{l}\text { - incorporating a large number of objects into the } \\
\text { landscape can sometimes be more difficult than one } \\
\text { large power plant }\end{array}$ \\
\hline
\end{tabular}




\begin{tabular}{|c|c|c|}
\hline 1 & 2 & 3 \\
\hline Scale effect & $\begin{array}{l}\text { - benefits resulting from the mass production of generation } \\
\text { units of distributed generation, } \\
\text { - lowering unit investment expenditures improves the } \\
\text { competitiveness of distributed generation }\end{array}$ & $\begin{array}{l}\text { - larger generation units of centralized generation tend to } \\
\text { have higher efficiency }\end{array}$ \\
\hline $\begin{array}{l}\text { Extending the unit's } \\
\text { power catalog }\end{array}$ & $\begin{array}{l}\text { - good prospects of adapting to demand thanks to smaller } \\
\text { differences between unit power }\end{array}$ & $\begin{array}{l}\text { - marginal costs can be higher than for large system } \\
\text { blocks }\end{array}$ \\
\hline System services & $\begin{array}{l}\text { - in individual events, the demand for system services may } \\
\text { decrease due to the unloading of system components }\end{array}$ & $\begin{array}{l}\text { - after the introduction of distributed generation, the } \\
\text { demand for system services may increase, especially } \\
\text { due to the need to reserve the power of these sources }\end{array}$ \\
\hline Power reliability & $\begin{array}{l}\text { - in the peripheral areas of the system, the security of the } \\
\text { recipients' power supply may increase }\end{array}$ & $\begin{array}{l}\text { - distributed generation can reduce the reliability of power } \\
\text { supply in the local network }\end{array}$ \\
\hline
\end{tabular}

Source: Pasek (2005), pp. 5-6.

The process of popularizing distributed generation, the basic element of which is renewable energy sources and cogeneration systems, is of fundamental importance for the energy policy of the West Pomeranian Region. As a result of the emergence of energy groups, the problem of determining regional energy systems appeared. Each energy group is located in several region. Administrative coverage of provinces and energy groups does not coincide.

Distributed generation of electricity is an important component of sustainable development, bringing measurable economic, ecological and social effects to the region. The high failure rate of the power grid in the West Pomeranian Region is a premise for dispersed generation. The limitations of the development of distributed electricity in our region and country are affected by such barriers as:

- biased perception of dispersed energy in the legal system,

- lack of solutions supporting small and individual energy producers,

- bad development of electricity infrastructure, as to the needs of recipients and producers of distributed energy,

- maintaining regulation of retail prices of the electricity market for households,

- no decision on the construction of cross-border connections,

- lack of mechanisms supporting the reduction of energy intensity of the economy,

- unfavorable architecture of the wholesale market,

- defective operating principles of the retail energy market,

- low transparency of the wholesale electricity market,

- excessive State Treasury fiscalism,

- no subsidies for producers of the renewable energy market,

- lack of pro-effective and pro-innovation policy to support renewable energy,

- lack of a broader concept of the state's information policy in the field of renewable energy sources.

The support system in force in Poland, which is a form of the so-called color certificates is a mechanism conducive to the popularization of distributed generation.

\section{Result}

The potential of wind energy is primarily related to the spatial distribution of open areas. Such areas are predominantly agricultural land, which in the West Pomeranian Region is 954.2 thous. ha (GUS, 2017, pp. 27-28). 
Based on the available data, it can be concluded that over $90 \%$ of the arable land in the West Pomeranian Region is suitable for technical use for the needs of wind energy (Michałowska-Knap, Wiśniewski, 2013, pp. 56-66).

For further estimates, it was assumed that the space demand in modern wind energy is 10 ha per $1 \mathrm{MW}$ of installed capacity (according to EWEA).

In the model, the existence of NATURA 2000 protected areas is a significant spatial limitation for the development of wind energy. In addition, a further limitation has been added from densely populated areas, where investments for wind energy purposes can not be implemented or encounter significant impediments in practice.

In West Pomeranian Region, $12.8 \%$ of arable lands are attractive areas for wind energy.

It is estimated that the potential of wind energy in West Pomeranian Region, taking into account environmental restrictions, is 12,200 (MW). With the assumptions made, this would correspond to the production of $26,600 \mathrm{GWh}$ per year.

In this scenario, it was assumed that $15 \%$ of agricultural land will be used for energy production from biomass, and the rest for commodity production. It was assumed that an average of 50,000 kWh can be obtained from ha of energy crops.

It is estimated that the West Pomeranian Region has a relatively high biomass potential, in the form of $7,156.5 \mathrm{GWh}$.

The main factors that shape the structure of agriculture in the West Pomeranian Region can include: a large area of farms, a favorable percentage of employees in agriculture and a focus on crop production. Due to the fact that organic fertilizers, such as manure and manure, are an important substrate for the production of agricultural biogas, it is also advisable to analyze the number of farm animals in the region. The dominant breeding animals are swine, cattle and poultry. According to CSO data, the number of cattle and pigs decreases, while the number of poultry increases.

The construction and operation of agricultural biogas plants can contribute to the improvement of this condition and inhibition of the downward trend. In spite of everything, it must be remembered that the construction of a biogas plant in a specific area must be confirmed in the form of biogas material. Therefore, animal husbandry near the installation should be compacted or run in large farms.

In addition to livestock production, the potential of biogas production is high in plants processing agricultural products, such as: sugar factories, distilleries, breweries, slaughterhouses or fruit and vegetable processing plants.

In West Pomeranian Region we are also dealing with a decreasing area of meadows and pastures. Assuming that $10 \%$ of this area will be used for energy purposes, we can get about 11.4 million $\mathrm{m}^{3}$ year biogas.

For the purposes of the biogas plant, cereals are also used, harvested in the appropriate phase and used as a supplementary substrate in the form of silage. The optimal vegetable substrate used in agricultural biogas plants is maize silage.

If we assume that for the cultivation of maize for energy purposes, 13.2 thousand can be allocated in the region. ha, we can assume that we will obtain 56.4 million $\mathrm{m}^{3}$ year biogas. By allocating sugar beet leaves to silage, you can get about 39.6 million $\mathrm{m}^{3}$ year biogas.

It is estimated that the potential of the In West Pomeranian Region on the basis of available resources, waste from the agro-food industry, organic fertilizers, grass from permanent grassland, sugar beet and maize leaves, makes it possible to obtain about $638.7 \mathrm{GWh}$ of electricity from biogas. 
The market potential of solar energy in the region has been estimated from the point of view of the recipients' needs and practical possibilities of satisfying them, not from the point of view of energy supply restrictions, the more so that the development of solar energy in decentralized systems is relatively least limited by environmental factors.

The total potential of solar energy in Poland is $19,341 \mathrm{TJ}$, or $5,372,5 \mathrm{GWh}$, with average solar exposure of around $1,100 \mathrm{kWh} / \mathrm{m}^{2}$. In West Pomeranian Region, with an average of $1,000 \mathrm{kWh} / \mathrm{m}^{2}$ of sunshine, it is 393.2 GWh of energy (Wiśniewski, 2011, pp. 46-47).

West Pomeranian Region due to ecological conditions and protected areas, has a small hydropower development potential of $14.3 \mathrm{GWh}$ (Jasiulewicz, Janiszewska, 2017, pp. 91-102). Table 2 presents the energy potential of the West Pomeranian Region.

Table 2. Energy potential of the West Pomeranian Region

\begin{tabular}{lc}
\hline \multicolumn{1}{c}{ The type of renewable energy } & $\begin{array}{c}\text { The energy potential } \\
\text { of the West Pomeranian Region GWh }\end{array}$ \\
\hline Wind farms & 26.6 \\
Installations producing energy from biogas & 638.7 \\
Installations producing energy from biomass & $7,156.5$ \\
Installations generating energy from solar energy & 393.2 \\
Hydroelectric power plants & 14.3 \\
\hline
\end{tabular}

Source: own study based on the model.

Depending on the technology of electricity production from renewable energy sources, power plants will produce a different amount of energy annually. This is due to the fact that especially power plants based on renewable energy sources rarely work with nominal power. Therefore, the model introduces a maximum power utilization factor to be able to compare individual technologies with each other. Table 3 shows the maximum power utilization rate.

Table 3. The maximum power utilization rate

\begin{tabular}{lccc}
\cline { 3 - 4 } & & & $\begin{array}{c}\text { Coefficient of use } \\
\text { maximum power (\%) }\end{array}$ \\
\hline Theoretical maximum production for 1 MW of power plant & 8.76 & GWh & 100.0 \\
Photovoltaic power plant & 0.97 & GWh & 11.1 \\
Wind power plant good location & 2.10 & GWh & 24.0 \\
Biomass power plant & 2.19 & GWh & 25.0 \\
Hydroelectric power plant & 2.70 & GWh & 30.8 \\
Biogas power plant & 3.35 & GWh & 38.3 \\
Waste power stadion & 2.75 & GWh & 31.5 \\
Coal power stadion & 6.90 & GWh & 78.8 \\
\hline
\end{tabular}

Source: Szymański (2012).

The model assumes that the West Pomeranian natural and climatic conditions predispose to the production of energy from wind farms, as well as biomass from economically untapped grassland and forest production. 
The model assumes that a large share in the production of electricity may be the agriculture of the region, which, apart from the basic function of food production for the population, will play the agroenergetic role.

It is assumed that energy crops should be competitive with commercial agricultural production and be an element of the market game.

The basic agrotechnical restrictions for particular groups of plants have also been adopted (max of the given crop in the structure of sowing and soil fertility) = in accordance with the principle of sustainable development.

It is also assumed that energy investments will be characterized by a high capital intensity and a long investment cycle, 5-10 years, as well as a long period of return of incurred investment outlays.

The assumptions of the model also assumed that there are wind farms, hydropower plants, biogas power plants at landfills, biomass production plants, including sawmills and electricity producing plants. Table 4 presents the solution of the regional model of distributed energy in the West Pomeranian Region.

Table 4. Solution of the regional model of distributed energy in the West Pomeranian Region

\begin{tabular}{|c|c|c|c|c|c|c|c|c|c|c|c|c|c|c|c|}
\hline $\begin{array}{l}\text { Types } \\
\text { of energy }\end{array}$ & $x_{1}$ & $x_{2}$ & $x_{3}$ & $x_{4}$ & $x_{5}$ & $x_{6}$ & $x_{7}$ & $x_{8}$ & $X_{9}$ & $x_{10}$ & $x_{11}$ & $x_{12}$ & $x_{13}$ & $x_{14}$ & $x_{15}$ \\
\hline $\begin{array}{l}\text { Energy } \\
\text { production }\end{array}$ & 0 & $3,016.5$ & 59.8 & 8.23 & 383.5 & 0 & $1,452.8$ & $1,502.2$ & 21.5 & 23.39 & 533.9 & 0 & 416.5 & $1,914.5$ & $9,333.4$ \\
\hline $\begin{array}{l}\text { Energy raw } \\
\text { materials }\end{array}$ & $x_{16}$ & $x_{17}$ & $x_{18}$ & $x_{19}$ & $x_{20}$ & $x_{21}$ & $x_{22}$ & $x_{23}$ & $\mathrm{x}_{24}$ & & & & & & \\
\hline Crop size & 0 & 0 & 0 & 0 & 0 & 0 & 0 & 0.059 & 0 & & & & & & \\
\hline
\end{tabular}

Source: own study based on the model.

In this scenario, we note that the total energy production in the West Pomeranian Region will be 9,333 GWh (i.e. we assume coverage of demand in the region), of which 3,016 GWh is energy production from co-firing, and $8 \mathrm{GWh}$ is hydropower created in new hydropower plants. In solar installations, $383 \mathrm{GWh}$ of energy can be generated. In the case of new wind power plants, as much as existing, there will be 2,955 GWh of energy generated. In both new and existing installations in the region, $638 \mathrm{GWh}$ of energy will be produced in general for biogas. The remaining 2,331 GWh of energy will be generated in new and existing installations producing energy from biomass combustion. The average construction cost of one MW in this energy scenario will amount to PLN 9,333,509, and the loss of soil fertility in this scenario will amount to $0.059 \mathrm{t} / \mathrm{ha}$.

\section{Conclusions}

1. The calculations of the original model confirm the possibility of building a regional model of dispersed energy, meeting the principles of sustainable development, increasing energy security and increasing energy efficiency and the full use of renewable energy.

2. The current state energy policy is not conducive to the creation of autonomous regional systems of dispersed energy, where the main decision-maker about the size and structure of the energy produced would be decided by the local government, not energy concerns and the Energy Regulatory Office.

3. Own research on the energy mix of the West Pomeranian Region indicate that it takes into account the specificity of the region to a small extent, where the main energy supplier is coal power. The only positive example is the development of wind energy. The constructed biomass power plant in Szczecin uses, to a small extent, local 
energy resources, coming from wastelands and permanent herbaceous land. It should be emphasized that a large part of the biomass comes from imports.

4. The constructed mathematical model and its validation confirm that it can be a tool to simulate the region's energy policy. Economic calculations indicate the validity of the current energy mix in the region, where coal is the dominant part.

5. The simulation carried out indicates that: the region is self-sufficient in energy, it can produce surplus energy with large investment outlays.

\section{References}

GUS (2017). Rolnictwo w województwie zachodniopomorskim w 2017 r. Szczecin.

Jasiulewicz, M., Janiszewska, D. (2017).Potencjalne możliwościrozwojubiogazownina przykładzie województwa zachodniopomorskiego, Inżynieria rolnicza. Koszalin: Wydawnictwa WIR.

Kasprzak, T. (1992). Systemy wspomagania decyzji wielokryterialnych. Warszawa: Wydawnictwa UW.

Michałowska-Knap, K., Wiśniewski, G. (2013). Analiza dotycząca możliwości określenia niezbędnej wysokości wsparcia dla poszczególnych technologii OZE w kontekście realizacji „Krajowego planu działania w zakresie energii ze źródeł odnawialnych”. Warszawa: Instytut Energii Odnawialnej, Ministerstwo Gospodarki.

Mokrzycki, E. (2003). Idea generacji rozproszonej. Nowe spojrzenie na środowisko. Nafta \& Gaz Biznes, październik. Retrieved from: https://odbiorcy-na-rynku-energii.cire.pl/pliki/2/ideageneracji.pdf.

Pasek, J. (2005). Wprowadzenie do wytwarzania rozproszonego energii elektrycznej i ciepła. Wiadomości Elektrotechniczne, 12, 5-6.

Skoczkowski, T., Baran, Ł. (2014). Model zrównoważonej produkcji energii z biomasy. Energetyka, 3 (717), 137-142.

Sobczyk, E., Wota, A., Krężołek, S. (2011). Zastosowanie matematycznych metod wielokryterialnych do wyboru optymalnego wariantu źródła pozyskania węgla kamiennego. Gospodarka Surowcami Mineralnymi, 27 (3), 34-39.

Strzelecki, R., Kukluk, J. (2000). Single phase active power line conditioners. In: Proc. 3-th International Symposium All Electric Ship Civil or Military - AES 2000 (pp. 379-384). Paris.

Strzelecki, R., Benysek, G., Dębicki, H. (2004). Uniwersalny wielofunkcyjny sprzęg międzysystemowy. Przegląd Elektrotechniczny, 3 , 226-232.

Szymański, B. (2012). Jak porównać moc elektrowni OZE z konwencjonalną. Solaris. Retrieved from: http://solaris18.blogspot. com/2012/11/jak-porownac-moc-elektrowni-oze-z.html.

Wiśniewski, G. (2011). Określenie potencjału energetycznego regionów Polski w zakresie odnawialnych źródeł energii - wnioski dla Regionalnych Programów Operacyjnych na okres programowania 2014-2020. Warszawa: Ministerstwo Rozwoju Regionalnego.

Cite this article aS: Rabe, M. (2018). Regional model of dispersed energy of the West Pomeranian Region. European Journal of Service Management, 4 (28/2), 365-372. DOI: 10.18276/ejsm.2018.28/2-43. 